\title{
Brand Trust between Social Networking and Brand Loyalty: SEM-PLS Approach
}

\author{
Raissa Abitha Daniswara ${ }^{1}$ Retnosari $^{1}$ Achmad Yanu Alif Fianto ${ }^{1 *}$ \\ ${ }^{I}$ Management Department, Faculty of Economy and Business, Universitas Dinamika, Indonesia \\ *Corresponding author. Email: achmadyanu@gmail.com
}

\begin{abstract}
This research examines the effect of social networking on brand trust and brand loyalty while simultaneously examining the role of brand trust mediation on the relationship between social networking and brand loyalty. Respondents in this study consisted of 100 consumers who use social networks and do beauty treatments at beauty clinics in Surabaya. Students in private universities and employees dominate the number of respondents in this research. To test the research hypothesis, this research adopted the Structural Equation Model-Partial Least Square (SEM-PLS) technique using SmartPLS. This research proves that brand trust has a significant influence on brand loyalty and a significant effect of social networking on brand trust. This research also found that social networking does not have a significant effect on brand loyalty. Therefore, this research also proves that brand trust has a full mediating role in the relationship between social networking and brand loyalty.
\end{abstract}

Keywords: Brand Trust, Social Networking, Brand Loyalty

\section{INTRODUCTION}

At present, treatment in beauty clinics is not the first choice for everyone, but now most people are starting to entrust their best facial skin in superior clinics[1]. Research conducted on women aged 20-40 years shows that women feel compelled to pamper themselves with beauty treatments and well-being that are continuouslyregulated to look better, as manyas $62 \%$ of women often visit prime care clinics and the normal frequency of visiting depletion centers and excellence clinics 2 times a month, with a budget for one treatment up to Rp 2.5 million[2]. In connection with research, it can prove that most womenuse beauty trends and are usually in line with the growing demand for beauty care products[3].

The demand for beauty products is growing from consumers, it is offset by the expansion of beauty goods in the best clinic[4]. Usually shown by the emergence of leading clinics in this country are very many[5]. However, not all leading clinics can be trusted, because not all leading clinics have BPOM archives and letters that are valid for their products. Health cases can be a warning for consumers to be more careful in choosing clinics or beauty products[6]. Indeed, despite the fact that there are superior clinics that violate the law, in fact there are still many beauty clinics that have legitimate reports and BPOM. This is a new thing in the world of skin welfare in Indonesia. In making a difference is not easy, because the expansion must continue to make development and methodology, but also must maintain customer service to thebrand[7].

Brand loyalty is an important part in a company's survival, because high devotion can increase supply[8]. Brand loyalty is the most important part of the companyfor survival, because high devotion can increase supply[9]. Brand loyalty is often measured by the number of repeat purchases made or influenced by the brand. If 


\section{Procedia Business and Financial Technology}

Proceedings of the 2nd International Conference on Business and M anagement of T echnology (ICO N BM T 2020) - Part 2

the customer executes and completes the brand item and the customer repurchases the brand, the shopper is called loyal. Brand dedication is part of the brand value.

If the customer is still working on costs, convenience, and so on, then the brand is not fair enough. If the buyer is stable on the brand, consumers will continue to use the brand, even though there is little good news around the brand. Brand loyalty measured by the consumer's best brand record. The ranking of the best brand records uses this survey to look at some of the criteria chosen by buyers, specifically mind the best share, the best ad share, and we can talk about brand dedication.

Brand trust is a feeling of trust and security of consumers interacting through brands, according to the belief that brands can be recognized, interact and secure with consumers. Brands believe that there is a long-term desire or potential of a brand to provide positive performance to its customers. Consumer confidence willbe formed if the brand is able to meet or exceed the desires of the buyer. Brand trust can be measured through life force measurement (practicality dimensions) and intentional measurement or intentionality measurement. Measurement of Practicality reflects the recognition that the brand can meet the desires and size of the buyer.

This estimation can be measured by the achievement and evaluation of markers (costs). Accidental measurement shows the comfort of a person to the brand. This estimation can be measured through the sense of security felt by consumers to the brand[10]. Therefore, brand trust is formed if it can satisfy the needs and values of consumers and consumers feel comfortable when using a brand. Some views argue that there are factors that can affect the brand, especially trust the brand or the so-called brand characteristics, company specialization or company characteristics[11]. The characteristics of the buyer's brand, producers directly believe in the loyalty of producers, brands and trust can form valuable relationships.

Nowadays, businesses can increase brand trust in various ways. One of them formed an action or campaign. This strategy is now widelyused bybusinesses to encourage criticism from consumers, so buyers increasingly recognize the brand and then trust the brand. Companies that need feedback about their brand and need to trust their customers can use social organizing media. The social system is the relationship between communities that feel intimate, as in terms of equalitysuch as fate, interests and work. Cognition, compassion, and mutual influence can be the core of a social system that can increase compatibility between individuals and brand communities[11]. Social media can influence customer behavior after buying.

From both views, these differences can be used as a basis for selecting variables, the question of whether brand variables believe in brand credibility. Today, the company builds brand trust in various ways. One of them formed an action or campaign[10]. Because this strategyis still widely used by businesses to encourage criticism from consumers, buyers increasingly recognize brands that trust these brands. Companies that are motivated for feedback and need buyers to be confident in brands can use socialmedia.

Social networks are basically relationships between communities because they feel the same in terms of imitation, interests and work. Gratitude, empathy, and reciprocity can be part of a social system that can increase mutual accountability and symmetry in a brand community. Social media can influence customer behavior by communicating post-purchase information. According to experts this is stated as a statement of dissatisfaction or post- purchase. Some opinions state that social media can strengthen acceptance, affection and the effect of action. Social media makes brands easily accepted, creating buyer's influence and affection.

Nowadays, most people spend time with social media like Instagram, Twitter and Facebook. Media Marketing and brand trust. Differing on brand trust and building trust in brand credibility, the impact of orange horns and social engagement are seen as supporting the brand. Social networking includes brand loyalty and the impact associated with brand trust. Therefore, brand trust is not currently a parameter. Under these circumstances, analysts are interested in examining the "social impact of social networks" on brand trust and brand loyalty. The bond between social networking with brand loyalty and intervention variables shows that brand trust and referral commitment are subject to more specific referrals.

\section{LITERATURE REVIEW HYPOTHESES DEVELOPMENT}

AND

\subsection{Brand Trust and Brand Loyalty}

Brand loyalty is seen as a pattern in the buying behavior of a brand, and provides advice for others to buythe brand[10]. In addition, brand loyalty is the view of consumers in making purchases on products or services. Brand loyalty can directly affect the satisfaction and disappointment of a brand that is collected during a certain period in the form of awareness of the quality ofgoods[11]. Brand loyalty is the quality ofcustomer relations to the brand. This level can make it possibleto consider whether a buyer can switch to other brands published byhis competitors, if changes are found in the brand in terms of the characteristics taken and othercharacteristics.

According to these two terms, it can be concluded that there are two points in brand loyalty, specifically: attitude and behavior. Behavior combines repurchase or repeat orders for a brand, while a state of intelligence combines the level of commitment to certain values associated with thebrand. 


\section{Procedia Business and Financial Technology}

Proceedings of the 2nd International Conference on Business and M anagement of T echnology (ICO N BM T 2020) - Part 2

Brand loyalty is a condition where a consumer has good behavior or attitude towards a brand, is committed to a particular brand so that he has the intention to buy again in the future. Brand loyalty is closely related to involvement in using the brand. Events of brand loyalty to buyers can be caused by the impact of fulfillment or disappointment on the brand that always piles up in the expansion to the recognition of the quality of goods. Buyers who are loyal to a brand of goods will buy back goods with the same brand. Buyers who have a positive perception about the brand's promise to shop in the future, use the goods to achieve fulfillment, and buyers are committed to the brand. Brand trust is that there is a notable impact on Brand loyalty using prices. Brands can be trusted and stated positive so that it has an impact on brand loyalty. Of the several notions that have been explained, there is a hypothetical formula shown as follows:

\section{H1 : The influence of brand trust on brand loyalty.}

\subsection{Social Networking and Brand Loyalty}

Social networking media sites as online technology knowledge and things to do where customers can change their opinions and knowledge. Social networking is social media that is based entirely on brand communities[2]. Communities that are now not hindered by the prerequisites of geographic location, are exclusive, which are mainly based on a collection of social interactions among followers of the company that are unique and provide a form of description that is contained in the condition of consumers involved in the use of a product. Brand-based social media organization is a combination of brand communities and social media locations, which leads to a broader concept than virtual communities and online-based brand communities.

This social event focuses on building, enhancing and maintaining bonds between people and the brand community. Social networking is one of several factors that contribute to managing brand loyalty[7]. Usually because social organizing may be the implication of nonstop communication around the brand, and increasingly convincing the buyer about the validity of the item so that the buyer can be loyal to a brand[2]. Beauty clinics in Surabaya have not significantly moved forward in improving social networking so that there are customers who use social media have not been encouraged in terms of information, benefits, and services provided by the product. The social networking variable has a good impact and is noteworthy on brand loyalty. Social media marketing includes an important impact on brand loyalty. Of the several notions that have been explained, there is a hypothetical formula shown as follows:
H2: The effect of social networking on brand loyalty.

$37 / 180$

\subsection{Social Networking and Brand Trust}

Brand communities on social organizing social networks incorporate positive impacts on brand trust. This could be since social networking makes a company difference to spread more in-depth information about the brand, thereby reducing fraud around the brand. In expansion, social networking is also an instrument to maintain interaction between companies and individuals, as well as individuals with sections that believe in the brand that is built. So social networking also includes a part in managing brandtrust.

Social media requires customers to create profiles, share some information, create interfaces, and send messages with other customers[7]. Because social organization is a well-known and self-evident area of progress in the community, progress in social organizations is used by marketers to advance in development strategies. Social Networking can be measured in several ways, including: (1) Brand communities whose members are interconnected; (2) Knowing each other's members; (3) Take good care in social networking; (4) Provision of information about products among members; (5) Needs that are considered by other members; (6) Accommodate some opinions from members about the product; (7) Appreciation and remarks from among members; and (8) Submission of opinions from members on social networking.

Furthermore, it is very important for companies to make rapid steps in the implementation of social networking using social media, because it can increase buyer certainty to continue to trust the brand[2]. Social networking combines positive and critical impactson brand trust[1]. The positive standard coefficient indicates that the social organization of a beauty clinic is superior, a better way of brand loyaltythan a beauty clinic. Social networking has an impact on brand loyalty because of experience. From some of the definitions that have been explained, there is a hypothesis formula shown as follows:

\section{H3 : The influence of social networking on brand trust.}

\section{RESEARCH METHOD}

\subsection{Research Design}

This research technique applies a quantitative approach. Quantitative approach is an approach utilizing search techniques such as experiments, surveys and structured facts in a number structure and analyzed based on statistical evaluations to show the impact of social networking on company loyalty mediated by the way 


\section{Procedia Business and Financial Technology}

Proceedings of the 2nd International Conference on Business and M anagement of T echnology (ICO N BM T 2020) - Part 2

brands have trust in buyers of beauty clinic in Surabaya. Quantitative methods, which use survey methods. Lookup surveys arequantitative findings about the use of the same organized or environmentally friendly questions for many people, due to the fact when answers have been obtained by the way researchers have been recorded, processed, and analyzed. Usually surveys are used to draw wideranging conclusions from pre-determined samples.

This observation is also a type of associative causal research. Associative casual research is carried out to find relationships and analyze the relationships between variables $\mathrm{X}$ and $\mathrm{Y}$. Causal relationships are defined as causal relationships, one of the independent variables that influences the dependent variable. In this observation, the independent variable is Social Networking (X), and the dependent variable is Brand Loyalty $(\mathrm{Y})$ and Brand Trust (Z) as intervening variables. According to the level of construction this research is associative research. Associative relationships are studies to investigate the cause. Relationship or influence of the independent variable

(X) with the dependent variable (Y).

\subsection{Population, Samples and Sampling}

The people included in the observation are consumers of products from the Beauty Clinic in Surabaya as well as those who use social networking. The population in this study are students and workers in Surabaya, East Java, Indonesia, who have used products from beauty clinics. The information gathering technique used in this observation is a questionnaire. In this analysis, the techniques used include descriptive analysis prerequisite test analysis and SmartPLS version 3 as a data analysis technique.

In this case think about using a nonprobability testing method. The nonprobability testing procedure is characterized as a sampling procedure where a researcher chooses samples based on their subjective judgment rather than random selection. This is an effiecient way that is not too strict and able to analyze properly. This sampling method is very dependent on the expertise of the researchers. The non-probability technique used in this consideration is purposive sampling. Purposive sampling can be a test chosen based on the characteristics of the population and the purpose of observation. Sample criteria used in this study include: (a) Beauty Clinic consumers in Surabaya who have made purchases or treatments (at least 1 time) and (b) Beauty Clinic consumers in Surabaya who use social networking.

\subsection{Data Collection Technique}

The information used as an idea for this is important information. Analysts in the field will receive the necessary information directly. Regarding the research strategy using a questionnaire, a strategy of gathering thought information was used. Surveys maybe organized questions that are used to obtain information. This survey is used to obtain respondents' information about social networking, brand trust and brand loyalty. The answers recorded in the investigation were given as defendants in this case.

As an important part of the survey, respondents provide personal information such as position, age, gender, occupation and monthlysalary. At that time, the respondent filled in two initial questions. If the respondent meets the criteria in the form of a test, the respondent can forward the question to the survey. Questions about the impact of social networking factors on brand trust are related to brand trust. Variables in the study include independent and dependent variable. Independent Variable can be either variables that have a positive or negative relationship with the dependent variable. In addition, this variable influences changes in the dependent variable. In reflection, there are independent variables, especially social networking. Social networking is a relationship between individuals, and they intimately and thus show the fate, interface, work, and other similarities. Indicator to measure these variables using five answer choices. Dependent Variable. The dependent variable is one of the most considered in the hypothesis. Witnesses can simultaneously predict or interpret factors in the dependent variable to see the changes that occur later. This poder dependent variable is brand dedication. The indicator to measure brand loyaltyuses five answer choices.

(3) Mediation Variables. The mediating variable in this question is brand trust. Brands believe that the brand has a high desire or relevance to bring good results to the buyer.

Signs of brand trust in utilizing the five choices of opinion assessment. The results of the data are said to be feasible to be used to examine if they meet the validity and reliability criteria. (1) Test Validity. Validity test is run to test the validity of the survey used. If the articulation can show what the survey measured, one survey is enough. Dealing with a 0.50 stack calculation means that the device can provide the same level of visibility and can be asked for the results of existing points. (2) Reliability Test. Reliability test is used to find out how precise and accurate an instrument is. A stable and consistent is a measurement in the reliability test. This measurement uses the Cronbach Alpha statistical test. Cronbach Alpha statistical tests tosee whether some Likert scale survey questions are reliable. if the designed test accurately measures the variable of interest. A construct or variable is said to be reliable if it gives a Cronbach Alpha value> 0.60 accepted. If the alpha results close to 1 , the data is categorized that theCronbach's alpha value is classified a $<0.60$ reliabilityis not strong, 0.6 $<\mathrm{a}<0.79$ reliability is accepted and a $>0.80$ is strong

(3)/180 


\section{Procedia Business and Financial Technology}

Proceedings of the 2nd International Conference on Business and M anagement of T echnology (ICO N BM T 2020) - Part 2

reliability.

\section{RESULTS}

Respondent characteristic data in this study amounted to 100 respondents. The characteristic data is that the Beauty Clinic consumers in Surabaya average age 17-23 years with a frequency of 94 people. For sex there are 97 people and men are 3 people. The work of beauty clinic consumers in Surabaya is more dominant among students with a total of 76 people. And as many as 56 people have monthly income of $\leq \mathrm{Rp} 1,000,000$.

The relationship between structure and indicators must be evaluated in the measurement phase of the model, namely convergent effectiveness and discriminant effectiveness. Adequacy of convergence can be achieved by evaluating indicators of validity, construct reliability, and Average Variance Extracted (AVE). The effectiveness index can be evaluated effectively because the factor load value is greater than 0.5 and the statistical value is greater than 2.0. The results showed all indicators of this study could be declared valid because they met the evaluation requirements of the indicators.

All factor loading values of the indicators used for the measurement of the variables studied in this observation are more than 0.5 and the significance of the loading factor test results with the $\mathrm{t}$ statistic. So it can be interpreted that the indicators in this study have good validity because the loading factor is the correlation between these indicators and their constructs. Table 1 shows that all loading factors have a t-value of more than 2.0 , so it is clear that all indicators included in this study can be said to have significant validity. A further measurement of convergent validity is to build reliability by assessing the reliability of composite or Cronbach's Alpha outputs. Ideal reliability has a composite reliability value of more than 0.70 and an Average Variance Extracted (AVE) value of more than

0.50. The AVE test and Composite Reliability, which proves that all constructs in this observation can be said to be reliable because they have a Composite value of more than 0.70 and AVE value of more than 0.50 .

Effective discriminatory measurement models are evaluated in two stages. In other words, measure the value of crossloading and compare the correlation between configurations with AVE values or compare the relationship between configurations with root AVE. Cross-load qualifications are highlighted with indicators that measure configuration. We can see that each indicator in this study correlates better with each construct with the other. Then proceed to the correlation comparison test using the AVE root construct shown in Table 5. As can be seen from Table 4, the maximum correlation value of marketing communication with other variables is 0.809 , and the base value of AVE is 0.8905 higher than the maximum correlation value. Likewise, the maximum correlation value for other variables in this study seems to be lower than the respective AVE values. Therefore, it can be concluded that this observation has good discriminant validity.

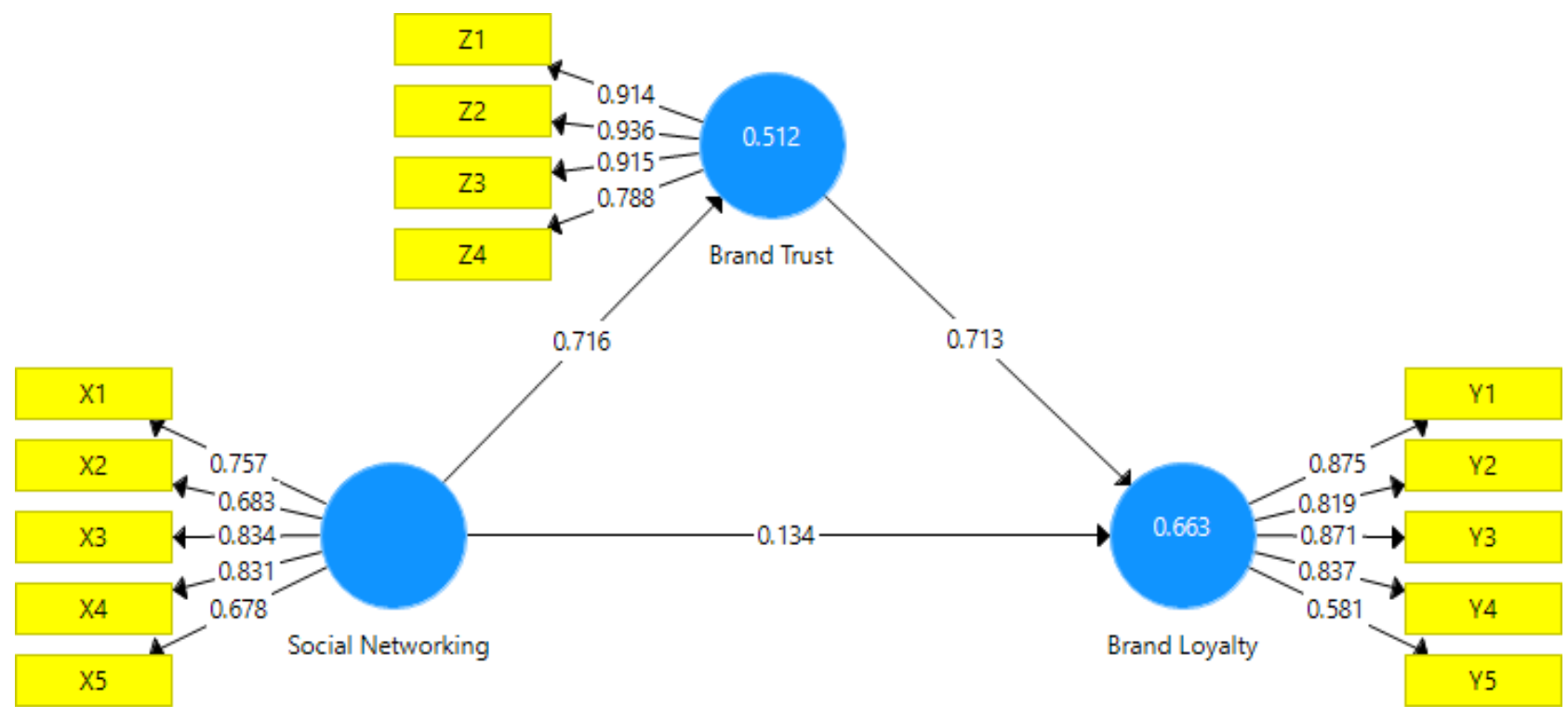

Figure 1 Result of PLS Algorithm Test 


\section{Procedia Business and Financial Technology}

Proceedings of the 2 nd International Conference on Business and M anagement of T echnology (ICO N BM T 2020) - Part 2

\section{DISCUSSIONS}

Based on the results of the study, it is known that the variable brand trust towards brand loyalty has a significance value of $0,000(0,000<0.05)$. Based on this it is stated that they believe that brand trust has a positive and significant effect on brand loyalty. Furthermore, based on the results of research on social networking variables have results of $0.214(0.214>0.05)$ on brand loyalty, this shows that the results obtained are not significant. The significance of social networking is $0,000(0,000<0.05)$. From these results, it can be seen that social networking has a good and significant impact on brand trust. The standard coefficient has a positive number indicating that the better the management of social networking, the better the brand trust in the Beauty Clinic inSurabaya.

\section{CONCLUSIONS}

Social networking has a significant impact in building brand trust. Good social networking can enhance the brand trust of beauty clinics in Surabaya. The insignificant impact of social networking on brand loyalty, because good social networking does not always increase brand loyalty. Significant impact of brand trust on brand loyalty, good brand trust can increase loyalty for brands owned by Beauty Clinic in Surabaya. The relationship between social networking and brand loyalty is the mediating effect of brand trust. Although the direct effect of social networking on brand loyalty is greater than the indirect effect, brand trust also affects brand loyalty..

\section{REFERENCES}

[1] A. Y. A. Fianto, "The Antecedents of Purchase Decision for Hijab Fashion Products," Manajemen, vol. 12, no. 1, pp. 154-165, 2020.

[2] A. Y. A. Fianto, "Satifaction As Intervening For The Antecedents OfIntention To Revisit: Marine Tourism Context In East Java," Relasi, vol. 16, no. 1, pp. 179-207, 2020.

[3] A. Marzuqi, "Penciptaan Motif Batik sebagai Ikon Kabupaten Lumajang," Institut Bisnis dan Informatika Stikom Surabaya, 2015.

[4] S. Lauwrentius, "Penciptaan City Branding melalui Maskot sebagai Upaya untuk Mempromosikan Kabupaten Lumajang," Unpublished Undergraduate Thesis, Visual Communication Design, 2015.

[5] R. D. Pinasti, A. Y. A. Fianto, and W. Hidayat, "Penciptaan Buku Komik Sebagai Upaya
Pengenalan Permainan Tradisional Kepada Remaja," Art Nouv., vol. 4, no. 1, 2015.

[6] E. Y. Ikawira and A. Y. A. Fianto, "Penciptaan Buku Ilustrasi Legenda Reog Sebagai Upaya Mengenalkan Budaya Lokal kepada Anak-Anak," Art Nouv., vol. 3, no. 1, 2014.

[7] R. Santoso and A. Y. A. Fianto, "Pengaruh Marketing Mix Produk Jasa terhadap Keputusan Berkunjung Wisata Bahari Jawa Timur," Kinerja, vol. 17, no. 1, pp. 69-79, 2020.

[8] R. Santoso, R. Shinta, and A. Y. A. Fianto, "Pengaruh Bauran Pemasaran Jasa terhadap Keputusan Berkunjung ke Wisata Bahari Jawa Timur," Manajdan Bisnis, vol. 4, pp. 1-14, 2019.

[9] D. Y. Riyanto, N. Andriyanto, A. K. Riqqoh, and A.Y. A. Fianto, "A Conceptual Framework for Destination Branding in Jawa Timur, Indonesia," Maj. Ekon., vol. XXIV, no. 1411, pp. 149-157, 2019.

[10] H. Song, J. Wang, and H. Han, "Effect of Image, Satisfaction, Trust, Love, and Respect on Loyalty Formation for Name-Brand Coffee Shops," Int. J. Hosp. Manag., vol. 79, no. June 2018, pp. 50-59, 2019, doi: 10.1016/j.ijhm.2018.12.011.

[11] M. Lude, "Why the Family Business Brand Matters: Brand Authenticity and the Family firm Trust Inference," vol. 89, no. September 2016, pp.

121-134, 2018, doi: 10.1016/j.jbusres.2018.03.040. 